\title{
PEMENUHAN HAK PARTISIPASI ANAK MELALUI FORUM ANAK DALAM IMPLEMENTASI KEBIJAKAN KOTA LAYAK ANAK DI KOTA BANDUNG
}

\section{(Studi Kasus Forum Komunikasi Anak Bandung)}

\author{
Oleh: \\ Devi Ayu Rizki, Sri Sulastri, dan Maulana Irfan \\ Email: \\ (deviayuriz@gmail.com; ati.sukaati@gmail.com;sangirfan@gmail.com)
}

\section{Pendahuluan}

Anak adalah harapan setiap orang tua dan keluarga. Dalam cakupan luas, anak adalah harapan bangsa dan negara bahkan dunia di masa yang akan datang. Oleh sebab itu, menjadi hal yang krusial dan komitmen bersama untuk memenuhi hak-hak anak sebagai manusia serta mewujudkan dunia yang layak bagi mereka.

Pada tahun 1989, Perserikatan Bangsa-Bangsa mengeluarkan Konvensi tentang Hak-hak Anak (KHA) dan menetapkan kewajiban bagi pemerintah yang meratifikasi untuk membuat langkah-langkah implementasi. Secara garis besar, Konvensi Hak-hak Anak (KHA) tersebut mengelompokkan hak-hak anak ke dalam 4 (empat) kelompok hak dasar, yaitu hak untuk bertahan hidup (survival rights), hak untuk tumbuh dan berkembang (development rights), hak atas perlindungan (protection rights), dan hak untuk berpartisipasi (participation rights).

Pemerintah Republik Indonesia telah meratifikasi konvensi tersebut pada tahun 1990 melalui Keppres Nomor 36 tahun 1990 kemudian mengesahkan Undang-undang Perlindungan Anak Nomor 23 tahun 2002. Dengan meratifikasi KHA, Indonesia menyepakati bahwa seluruh hak anak adalah hak asasi manusia seorang anak yang setara pentingnya dan bahwa Indonesia akan melakukan segala upaya untuk memastikan seluruh hak tersebut dihormati, dilindungi, dan dipenuhi.
Sejak diratifikasi Konvensi Hak Anak, pemerintah mulai menyusun berbagai strategi untuk membuat kebijakan maupun program yang betujuan untuk mewujudkan hak-hak anak. Salah satunya adalah Peraturan Menteri Pemberdayaan Perempuan dan Perlindungan Anak Republik Indonesia Nomor 11 Tahun 2011 Tentang Kebijakan Pengembangan Kota Layak Anak. Terdapat 40 kabupaten dan 34 kota di Indonesia yang telah dicanangkan sebagai salah satu kabupaten/kota menuju layak anak.

Bandung adalah kota yang pertama kali memiliki inisiatif untuk mengembangkan Kota Ramah Anak pada tahun 2004. Pada tahun 2006 Kota Bandung telah mendapatkan dua penghargaan sebagai pemerintahan yang memiliki komitmen kuat dalam upaya perlindungan anak sehingga telah dicanangkan sebagai Kota Layak Anak.

Dalam kebijakan ini, salah satu prinsipnya adalah partisipasi anak dalam pembangunan lingkungan yang juga sebagai salah satu hak dari 31 hak anak. Menurut Peraturan Menteri Pemberdayaan Perempuan dan Perlindungan Anak Republik Indonesia Nomor 3 Tahun 2011 Pasal 1 Ayat 2, "Partisipasi Anak adalah keterlibatan anak dalam proses pengambilan keputusan tentang segala sesuatu yang berhubungan dengan dirinya dan dilaksanakan atas kesadaran, pemahaman serta kemauan bersama sehingga anak dapat menikmati hasil atau mendapatkan manfaat dari keputusan tersebut. Anak perlu dilibatkan dalam pengambilan keputusan, termasuk dalam pengambilan keputusan rencana 
pembangunan daerah untuk mewujudkan kota yang layak bagi mereka.

Hal di atas menunjukkan bahwa partisipasi anak sesungguhnya merupakan dasar dan batu pijakan yang menjamin bahwa anak-anak merupakan subyek dari hak asasi manusia yang sama sehingga tidak selalu menjadi objek dari suatu proses pembangunan. Saat ini, pemerintah telah membentuk dan membina wadah partisipasi anak yang disebut Forum Anak, yang didalamnya beranggotakan seluruh anak dan pengurusnya terdiri dari perwakilan kelompok-kelompok anak. Forum anak ini dibentuk dengan tujuan untuk menjembatani kepentingan anak-anak dan kepentingan orang dewasa. Forum anak merupakan media, wadah atau pranata untuk memenuhi hak partisipasi anak tersebut, untuk secara khusus menegaskan pasal 10 Undangundang Nomor 23 tahun 2002 tentang Perlindungan Anak. Sebagai bentuk komitmen dalam merespon kesepahaman atas pentingnya hak partisipasi anak untuk mewujudkan Dunia yang layak bagi anak, Pemerintah Kota Bandung juga membentuk dan membina wadah partisipasi anak (forum anak) yang bernama Forum Komunikasi Anak Bandung (FOKAB).

Akan tetapi, hal ini agaknya juga masih sulit diimplementasikan. Anak sampai saat ini masih berada dilatarbelakang saja dalam proses pembangunan. Kesejahteraan anak diasumsikan akan terjadi bila pembangunan berjalan dengan baik. Jadi anak hanya ada dalam anggapan dan tidak pernah dikedepankan secara sadar dan sengaja sebagai wawasan pembangunan dan bukan subyek pembangunan. Mereka hanya menjadi indikator pembangunan, seperti angka kematian bayi, angka kematian balita dan anak, derajat partisipasi dalam pendidikan, dan sebagainya.

Konsep anak sendiri juga masih bias. Anak dipandang sebagai orang dewasa yang belum 'jadi', atau tengah dalam proses 'menjadi', sehingga tidak perlu diperhitungkan. Padahal anak adalah warga negara yang penuh akal, yang mampu membantu pembangunan masa depan lebih baik bagi semua orang.
Berdasarkan pernyataan tersebut, penelitian ini dilakukan dengan tujuan untuk mengetahui sejauh mana pemenuhan hak partisipasi anak melalui forum anak dalam implementasi kebijakan kota layak anak.

\section{Metode}

Metode yang digunakan pada penelitian ini adalah metode penelitian kualitatif deskriptif yang bertujuan untuk menjelaskan gambaran pemenuhan hak partisipasi anak dalam implementasi kebijakan kota layak anak di Kota Bandung, dalam hal ini peneliti mengambil studi deskriptif pada Forum Komunikasi Anak Kota Bandung (FOKAB).

Dengan demikian, laporan penelitian ini akan berisi penjelasan untuk memahami sebuah proses dan pemaknaannya secara lebih dalam melalui interpretasi. Penelitian deskriptif dipilih karena dalam pemenuhan hak partisipasi anak terkait perencanaan pembangunan kota layak anak terdapat tahapan dan mekanisme pelaksanaan melalui forum anak hingga menuju ke musyawarah perencanaan pembangunan daerah.

Dalam penelitian ini peneliti berperan sebagai pengamat partisipan dan kehadiran peneliti di lapangan diketahui oleh subjek penelitian atau disebut observasi partisipatif. Observasi partisipatif, yaitu pengumpulan data melalui observasi terhadap objek pengamatan dengan langsung hidup bersama, merasakan serta berada dalam aktivitas kehidupan objek pengamatan. (Burhan Bungin, 2011: 124). Di samping itu, peneliti menggunakan instrumen pengumpulan data dan menyimpulkannya. Data dalam penelitian ini dikumpulkan dengan menggunakan teknik wawancara, observasi, dan studi dokumentasi.

Untuk menjaga keabsahan data peneliti melakukan ketekunan pengamatan, konsultasi dengan pembimbing, dan diskusi dengan teman. Analisis data penelitian ini dilakukan secara kualitatif. Bogdan sebagaimana dikutip Sugiyono (2007:244) menyatakan bahwa analisis data kualitatif adalah proses mencari dan menyusun secara 
sistematis data yang diperoleh dari hasil pengamatan sehingga mudah dipahami dan temuannya dapat diinformasikan kepada orang lain.

Aktivitas analisis data penelitian ini meliputi identifikasi/reduksi data, penyajian data, dan penarikan simpulan. Kegiatan reduksi data dilakukan dengan merangkum, memilih hal-hal yang pokok, memfokuskan pada hal-hal yang penting untuk memudahkan menganalisis kualitas partisipasi anak di Kota Bandung dan mengidentifikasi kelengkapan data. Tahap selanjutnya adalah penyajian data. Data yang disajikan dari penelitian ini adalah data hasil dari lapangan yang telah direduksi dan disajikan dalam bentuk uraian singkat, bagan, hubungan antar kategori, dan sejenisnya dengan menggunakan teks yang bersifat naratif sehingga temuannya dapat dengan mudah dipahami orang lain. Tahap terakhir analisis ini adalah penarikan simpulan. Simpulan penelitian ini diambil dari intisari-intisari pembahasan terhadap hasil penelitian sehingga diperoleh simpulan yang kredibel.

\section{Hasil dan Pembahasan}

Kota Bandung merupakan salah satu kota yang dicanangkan sebagai salah satu Kota Layak Anak di Indonesia. Pemerintah Kota Bandung mulai mempersiapkan pembangunan daerah yang layak bagi anak, bukan hanya untuk saat ini, tetapi juga untuk di masa yang akan datang. Tentunya hal ini perlu melihat pertimbangan-pertimbangan dari anak itu sendiri sebagai subjek dari pembangunan. Oleh karena itu, dibentuk sebuah wadah partisipasi anak di Kota Bandung, yakni Forum Komunikasi Anak Bandung (FOKAB).

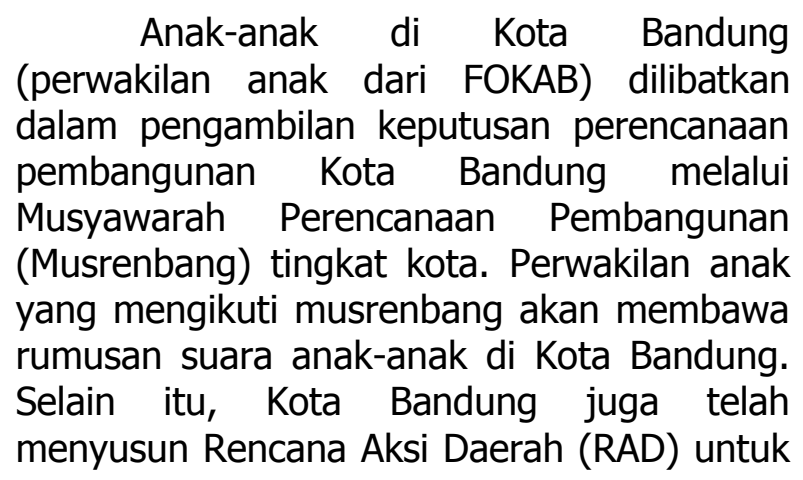

penyelenggaraan pembangunan Kota Layak Anak.

Akan tetapi, pada pelaksanaannya masih banyak orang dewasa pada tataran pemerintah Kota Bandung, khususnya yang membawahi bidang perlindungan anak, belum paham mengenai partisipasi anak dan peran forum anak (FOKAB) dalam pembangunan kota layak anak di Kota Bandung. Bahkan diantaranya masih bekerja dengan etika yang kurang ramah terhadap anak sehingga saat ini anak belum banyak terlibat dalam pengambilan keputusan perencanaan pembangunan Kota Bandung. FOKAB masih menemui kendala sulitnya mengakomodir suara-suara anak di Bandung. Aspirasi anak belum menjadi prioritas dalam pembangunan Kota Bandung karena legalisasi FOKAB melalui Surat Keputusan (SK) Walikota hingga saat ini pun belum terealisasi. Partisipasi anak di Kota Bandung masih dalam tahapan untuk pemberian informasi dalam musyawarah perencanaan pembangunan, bahkan ada juga indikasi manipulasi untuk memenuhi persyaratan atau indikator keberhasilan dari kebijakan Kota Layak Anak.

Selain itu, belum banyak fasilitator anak yang paham dan terlatih mengenai Konvensi Hak Anak dan peraturan lainnya yang terkait anak dalam memfasilitasi FOKAB menjalankan perannya sebagai perwakilan anak di Kota Bandung sehingga usulanusulan pembangunan maupun program dari FOKAB belum dapat disuarakan dengan baik ke pemerintahan Kota Bandung. Meskipun anak memiliki kemampuan dan daya kreativitas yang tidak terbatas, anak tetap butuh pendampingan dari orang dewasa untuk memastikan hak-haknya diperoleh dan dipenuhi.

\section{Simpulan}

Partisipasi anak sejatinya adalah melibatkan seluruh unsur masyarakat termasuk anak untuk berperan aktif. Hal ini dimaksudkan supaya anak dapat bertanggung jawab dan menikmati hasil pembangunan tersebut. Hak partsipasi bagi anak dalam kaitannya pembangunan Kota Layak Anak perlu disadari oleh semua pihak. 
Pemenuhan hak tersebut harus sesuai dengan pedoman yang telah ada dan memperhatikan kepentingan terbaik bagi anak.

Forum Komunikasi Anak Bandung (FOKAB) dibentuk sebagai salah satu wadah partisipasi anak di Kota Bandung. Forum ini kemudian haruslah dibina dan difasilitasi supaya peran dan fungsinya dapat berjalan dengan baik. Peran pendamping dan fasilitator cukup strategis untuk mendorong partisipasi aktif dari anak-anak serta mensosialisasikan ke seluruh pemangku kepentingan di Kota Bandung untuk melibatkan anak dalam pembuatan perencanaan program maupun kebijakan terkait pembangunan Kota Bandung menuju kota yang layak anak. Selain itu, perlu adanya legalitas atau payung hukum yang bagi FOKAB supaya setiap Satuan Kerja Perangkat Dinas (SKPD) di Kota Bandung concern terhadap isu-isu anak dan mempertimbangkan pendapat anak dalam perencanaan program maupun pembangunan.

\section{Daftar Pustaka}

Hart, Roger. 1992. Children's Participation: From Tokenism to Citizenship. UNICEF: Florence

Bungin, Burhan. 2011. Penelitian Kualitatif. Jakarta: Kencana

Peraturan Menteri Negara Pemberdayaan Perempuan dan Perlindungan Anak Republik Indonesia Nomor 03 Tahun 2011 Tentang Kebijakan Partisipasi Anak dalam Pembangunan.

Peraturan Menteri Negara Pemberdayaan Perempuan dan Perlindungan Anak Republik Indonesia Nomor 12 Tahun 2011 Tentang Indikator Pelaksanaan Kabupaten/Kota Layak Anak.

Panduan Partisipasi Anak dalam Perencanaan Pembangunan, Kementerian Pemberdayaan Perempuan dan Perlindungan Anak, 2014.

Pedoman Pengembangan Forum Anak Nasional, Kementerian Pemberdayaan Perempuan dan Perlindungan Anak, 2012.
Undang-undang Nomor 23 Tahun 2002 Tentang Perlindungan Anak 